\title{
A NORTHERN RECORD OF PANTROPICAL SPOTTED DOLPHINS (Stenella attenuata) IN SOUTHWEST ATLANTIC OCEAN
}

\section{Um registro mais setentrional de golfinhos-pintados-pantropicais (Stenella attenuata) no Atlântico Sul Ocidental}

\author{
Lívio Moreira de Gurjão \\ Analista ambiental, Instituto Brasileiro do Meio Ambiente e dos Recursos Naturais Renováveis (Ibama). \\ E-mail: livio.gurjao@gmail.com
}

\begin{abstract}
Pantropical spotted dolphins, Stenella attenuata, are found across all tropical and subtropical oceans around the world, but their distribution is poorly known in the Southwestern Atlantic Ocean (SWA). A group of approximately $10 \mathrm{~S}$. attenuata individuals was sighted in deep $(\sim 3,000 \mathrm{~m})$, warm $\left(\sim 27.5^{\circ} \mathrm{C}\right)$ and oligotrophic waters, near oceanic banks off northeastern Brazil $\left(02^{\circ} 04^{\prime} 16.68^{\prime \prime} \mathrm{S}\right.$ and $\left.038^{\circ} 08^{\prime} 28.26^{\prime \prime} \mathrm{W}\right)$. This sighting constitute a new record of the northern distribution of S. attenuata in SWA. More survey efforts must be carried out to investigate cetaceans distribution along the Brazilian coast, especially in offshore waters.
\end{abstract}

Keywords: marine mammals, cetaceans, Atlantic Ocean, Northeastern Brazil, oceanic banks.

\section{RESUMO}

Golfinhos-pintados-pantropicais, Stenella attenuata, são encontrados em todos os oceanos tropicais e subtropicais do mundo, mas sua distribuição no Atlântico Sul Ocidental (ASO) é pouco conhecida. Um grupo de aproximadamente 10 indivíduos de S. attenuata foi avistado em águas profundas (c. $3.000 \mathrm{~m})$, quentes $\left(c .27,5^{\circ} \mathrm{C}\right)$ e oligotróficas, próximas a bancos oceânicos do Nordeste do Brasil (0204'16.68" S e 038 $\left.08^{\circ} 28.26^{\prime \prime} W\right)$. Esse avistamento representa um novo registro para a distribuição mais setentrional de S. attenuata no ASO. Maiores esforços para investigar a distribuição de cetáceos ao longo da costa brasileira precisam ser realizados, especialmente em águas oceânicas.

Palavras-chave: mamíferos marinhos, cetáceos, Oceano Atlântico, Nordeste brasileiro, bancos oceânicos. 


\section{INTRODUCTION}

Pantropical spotted dolphins, Stenella attenuata (Gray, 1946), are found across all tropical and subtropical oceans around the world, where different populations have been described (Perrin, 1975; 2001). Although its distribution is generally restricted to pelagic tropical zones (e.g. S. attenuata attenuata and two informally named subspecies: S. attenuata subspecies A, found in the eastern Pacific, and S. attenuata subspecies B, surrounding Hawaiian Islands), a coastal form (S. attenuata graffmani) is also recognized for the Eastern Tropical Pacific (hereafter, ETP) (Perrin, 1975; Jefferson et al., 1993; Rice, 1998).

This species is well documented in the Pacific Ocean, where ETP offshore populations suffered substantial losses as a result of bycatch by purse-seine fishing vessels targeting yellowfin tuna (Thunnus albacares (Bonnaterre, 1788) (Gerrodette et al., 2012; Scott et al., 2012; Lennert-Cody et al., 2016). Even though these dolphin stocks appear to be recovering at a slower rate than expected after the implementation of measures to reduce their mortality in fishing nets (Wade et al., 2007; Kellar et al., 2013), S. attenuata has been listed as 'Least Concern' by the International Union for Conservation of Nature since 2008 (Kiszka \& Braulik, 2018).

In contrast to the ETP populations, the geographical range of pantropical spotted dolphins in the Atlantic Ocean is poorly known (Mignicci-Giannoni et al., 2003), especially in the Southwestern region (hereafter, SWA) (Moreno et al., 2005; Amaral et al., 2015). The species latitudinal distribution in SWA seems to be limited to Brazilian waters, since previous records south of $23^{\circ} \mathrm{S}$ are questionable and confirmed reports come solely from Rio de Janeiro state (Moreno et al., 2005), whereas other studies had documented its northernmost occurrences in Pará (Siciliano et al., 2008) or Maranhão states (Costa et al., 2017).

The present work reports a new record of the northern distribution of S. attenuata in SWA, in Brazilian offshore waters.

\section{MATERIAL AND METHODS}

Between $10^{\text {th }}$ and $12^{\text {th }}$ of June 2019, public agents from the Brazilian Navy, Federal Policy and the Brazilian Institute of Environment and Renewable Natural Resources IBAMA aboard the offshore patrol ship Macau (hereafter, NPa Macau) inspected fishing boats along Ceará state coastal waters and oceanic banks (up to c. 140nm from the coast).

Toward the end of a patrolling day, dolphins were opportunistically sighted and filmed with a 12-megapixel smartphone camera, able to record $4 \mathrm{~K}$ videos at 30 frames per second. After a first visual recognition, the video footage was carefully examined and compared to relevant references on cetacean identification (Perrin et al., 1987; Perrin, 2001, 2018) to assure the species had not been misidentified to assure the species had not been misidentified.

Geographic coordinates were taken from the vessel's GPS system (datum WGS84), while chlorophyll a concentration at a minimum depth (Chl-a) was obtained from BioORACLE (Oceans Rasters for Analysis of Climate and Environment, available at http:/ / www.bio-oracle.org/explore-data.php) (Tyberghein et al., 2012; Assis et al., 2017), bathymetric data were gathered from the U.S. Bathymetric and Fishing Maps (NOAA, 2019) and sea surface temperature (SST) and salinity (SSS) data obtained from PIRATA (Prediction and Research Moored Array in the Tropical Atlantic) buoy plots (NOAA, 2020), 
since biological and oceanographic parameters should be collected to investigate environmental features that influence the habitat and distribution of dolphins (Moreno et al., 2005). PIRATA Station $0^{\circ} / 35^{\circ} \mathrm{W}$ was chosen as reference as it was the closest buoy to the site where the dolphins were observed (c. $423 \mathrm{~km} / 228 \mathrm{~nm}$ distant).

\section{RESULTS}

On $11^{\text {th }}$ of June 2019 , at 04:05 p.m. (UTC-3, BRT), a group of pantropical spotted dolphins (c. 10 individuals, no calves sighted) was observed in oceanic waters off Ceará state $\left(02^{\circ} 04^{\prime} 16.68^{\prime \prime} \mathrm{S}\right.$ and $\left.038^{\circ} 08^{\prime} 28.26^{\prime \prime} \mathrm{W}\right)$.

In spite of the light spotting patterns of the observed individuals and the indiscernible flipper stripe, the other species characteristics enabled the precise identification of $S$. attenuata (Figure 1).

Figure 1 - Footage frames of $S$. attenuata sighted off Ceará State, Brazil (A-D), showing distinguishable characteristics of the species ( 1 - dark grey band encircling the eye continues forward to the apex of the melon; 2 - melon separated from the long thin beak by a distinct crease; 3 - distinct white beak tip; 4 - narrow, falcate and pointed at the tip dorsal fin; 5 - peduncle divided into dark upper and light lower portions; 6 - no spinal blaze sweeping up into the dorsal cape; 7 - dark dorsal cape, narrow on the head and sweeping low on the flank in front of the dorsal fin; 8 - grey lower side of the belly, where spots were more perceptible)

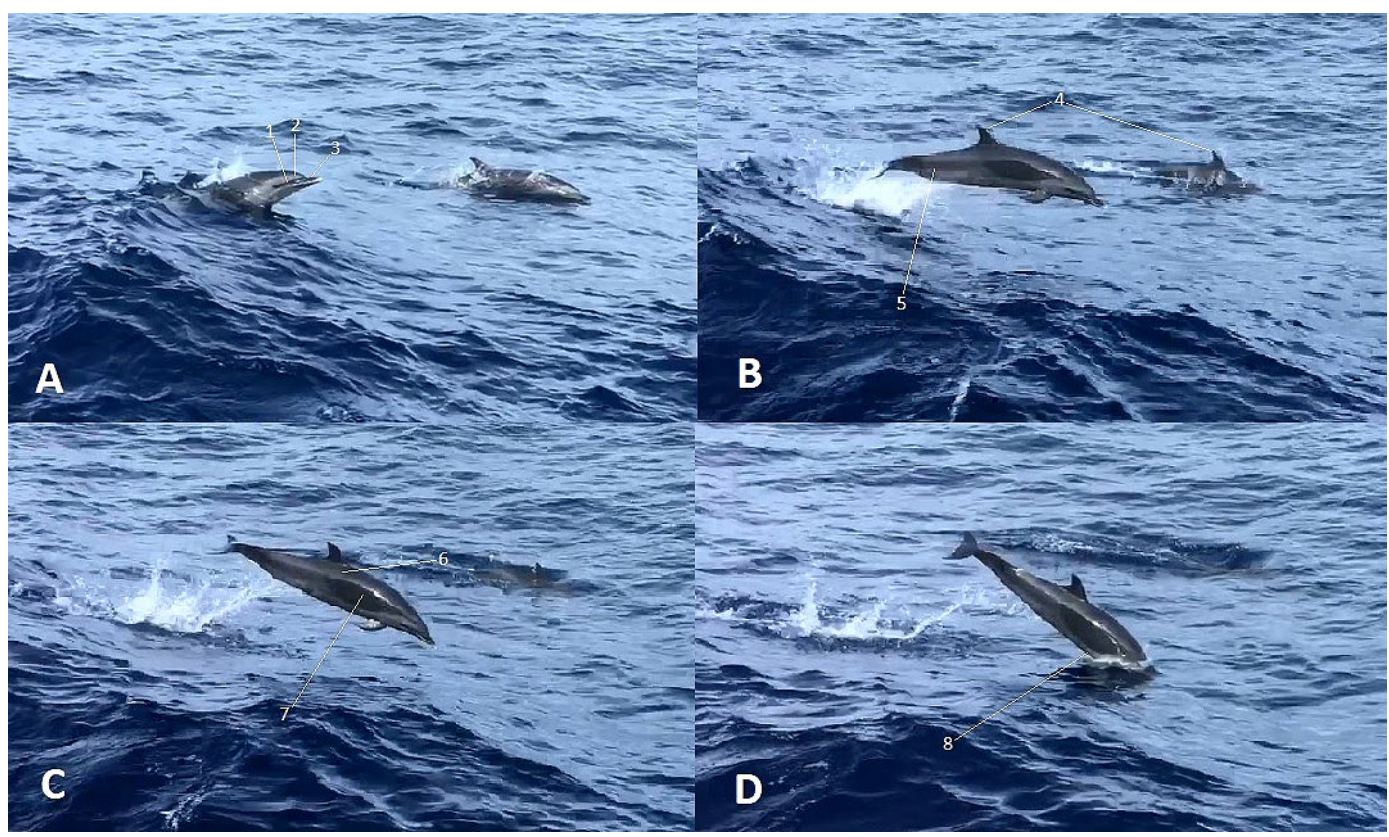

These dolphins swam for about 8 minutes along the same course as the NPa Macau ( $210^{\circ}$ heading), at c. 3,000 $\mathrm{m}$ deep, in the vicinity of the Canopus Bank, in the southeastern portion of the North Brazilian Submerged Seamount Chain (Figure 2). At that time, the vessel was traveling at a speed of $11 \mathrm{~km} / \mathrm{h}(6 \mathrm{~nm})$, when some of the dolphins moved beside it and crossed its bow, while other individuals leaped slightly away from the ship.

The day was overcast, in an area where mean Chl-a concentration is $0.004 \mathrm{mg} / \mathrm{m}^{3}$ (ranging from a minimum of $0.001-0.151 \mathrm{mg} / \mathrm{m}^{3}$ to a maximum of $0.004-0.488 \mathrm{mg} / \mathrm{m}^{3}$, depending on the region of the oceanic banks), whereas SST and SSS were $26.3{ }^{\circ} \mathrm{C}$ and 35,85 , respectively, at that time of the day. 
Figure 2 - Location of pantropical spotted dolphins record off Brazilian coast, where green line represents the Equator. The bathymetric map of the oceanic banks near Ceará state (red frame) presents the exact sighting position of S. attenuata (red cross)

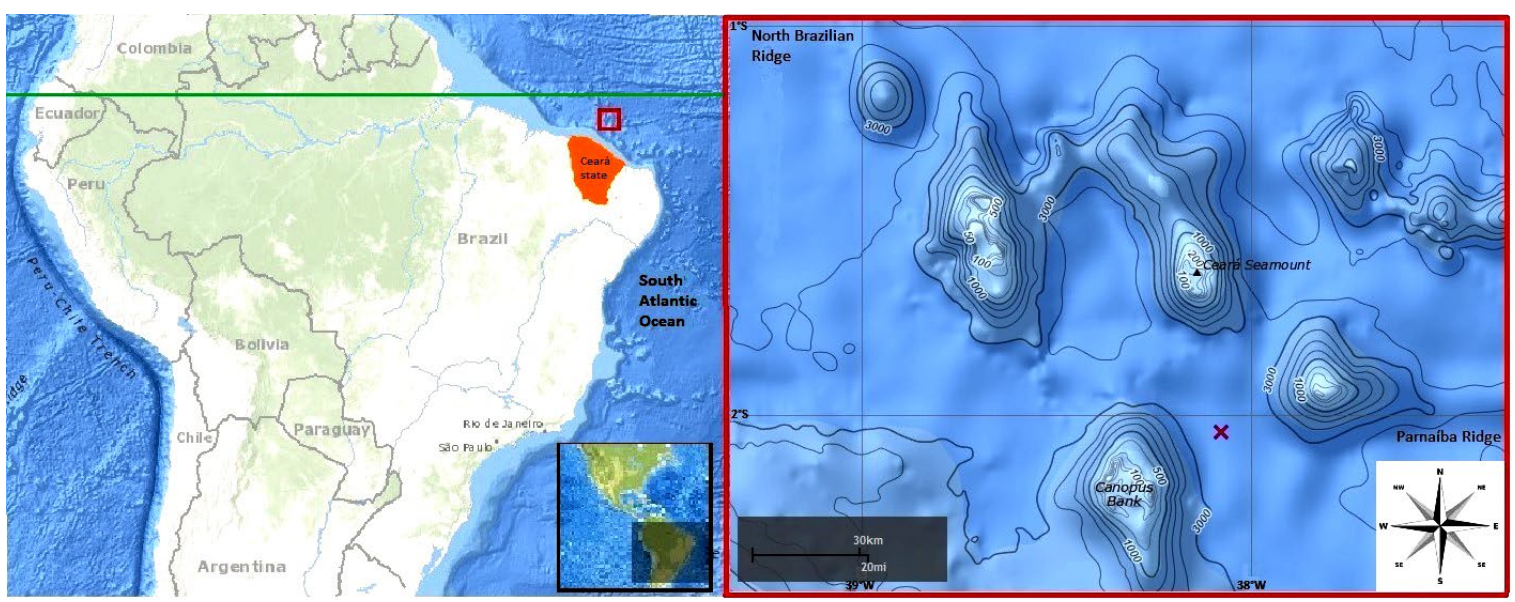

\section{DISCUSSION}

The scarcity of sightings of cetaceans in SWA is due to a combination of factors, including the limited cetacean-oriented survey efforts in deep waters along the Brazilian coast (Di Tullio et al., 2016; Rocha et al., 2019). Hence, most of the studies concerning the occurrence of such marine mammals in this area is based on a few localized records of strandings, accidental captures and opportunistic sightings (Rocha et al., 2019) and, so, the report of new occurrences, mainly in offshore waters, is extremely valuable to understand the distribution of cetacean species in this region.

Although all Stenella dolphins are currently well characterized, due to previous taxonomic uncertainties caused by similarities of external color pattern among some species and the overlap in their ranges, many records have remained unidentified or even been misidentified (Moreno et al., 2005). Pantropical spotted dolphins, for instance, can be confused with other long-beaked species, especially with the Atlantic spotted dolphin, Stenella frontalis (Cuvier, 1829), which is found only in the Atlantic Ocean (Perrin et al., 1987; Jefferson et al., 1993; Rice, 1998).

Nevertheless, S. attenuata and S. frontalis present a parapatric distribution along the eastern coast of South America. While the former occurs in waters beyond the slope, the latter is more often observed over the continental shelf (Amaral et al., 2015; Di Tullio et al., 2016) - despite a possible intersection area of the two species off the southeastern Brazilian coast (Moreno et al., 2005). Additionally, pantropical spotted dolphins can be differentiated from Atlantic spotted dolphins by the absence of a spinal blaze sweeping up into the dorsal cape and the presence of a clear division of the peduncle into dark upper and light lower portions (Perrin et al., 1987; Perrin, 2001; Mignicci-Giannoni et al., 2003; Lodi \& Borobia, 2013).

Flipper stripe and spotting patterns in $S$. attenuata are known to be highly variable with age, sex and also geographically (Perrin et al., 1987; Perrin, 2001). While specimens from the US Atlantic coast, Gulf of Mexico, coasts of Central and South America and also of West Africa have medium to heavy spotting, individuals from offshore Northwestern Atlantic and Southwestern Caribbean have fewer if any spots (Perrin et al., 1987; MignicciGiannoni et al., 2003). Thus, the unnoticeable flipper stripe and light spotting patterns here reported can be a typical feature of the offshore population from the northernmost SWA. 
As dolphin habitats appear to be a function of the variables influencing the aggregation of their preys (e.g. sea-floor relief, diffuse attenuation, Chl-a, SST, SSS and depth), these parameters affect the occurrence of prey species and, consequently, limit their distribution (Moreno et al., 2005; Amaral et al., 2015; Barragán-Barrera et al., 2019).

At the oceanic banks in the southeastern portion of the North Brazilian Ridge, the high SST (c. $27.5^{\circ} \mathrm{C}$ ) with narrow temperature range (c. $2.5^{\circ} \mathrm{C}$ ) and deep waters (around 3,000 m), make those areas highly suitable for the occurrence of $S$. attenuata (Amaral et al., 2015; Di Tullio et al., 2016). Indeed, the current sighting confirmed the ecological niche modeling presented by Amaral et al. (2015) and corroborate with the statement regarding the occurrence of pantropical spotted dolphins mainly in Northeastern Brazil, typically in small groups (up to 25 individuals), beyond the continental shelf break, in deep (850-4,900 $\mathrm{m})$ and warm $\left(26-28^{\circ} \mathrm{C}\right)$ waters (Moreno et al., 2005).

Although the oceanic banks off the Ceará coast present low Chl-a concentrations, they are recognized by local fishermen as economically important fishing areas (Bezerra, 2013) and may be attractive to $S$. attenuata, which feed on a wide variety of epipelagic and mesopelagic preys (Perrin, 2001). The confirmed occurrence of S. attenuata in areas of lower primary productivity corroborate with the results of ecological niche modeling of Stenella dolphins in the Caribbean Sea and SWA (Amaral et al., 2015; Barragán-Barrera et al., 2019).

More than 20 different cetacean species have been recorded within the coastal and offshore waters of Ceará state (Alves Júnior et al., 1996; Martins et al., 2004; Meirelles \& Furtado Neto, 2004; Meirelles et al., 2009, 2010, 2011; Ribeiro et al., 2011; Cypriano-Souza et al., 2016), including unpublished strandings of S. attenuata reported by Associação de Pesquisa e Preservação de Ecossistemas Aquáticos - Aquasis (Negrão \& Carvalho, pers. comm.). Thus, the sighting of pantropical spotted dolphins in this region was not unexpected, since this species is mostly sighted off northeastern South America (Moreno et al., 2005), where the environmental requirements for the occurrence of the species are present (Amaral et al., 2015). Probably, the reason why this species is scarcely recorded in north and northeastern Brazil is due to a lack of dedicated research efforts, especially in offshore waters at low latitudes in SWA (Amaral et al., 2015).

Costa et al. (2017) reported two stranded specimens of S. attenuata in Maranhão and Piauí states (between $2^{\circ} 50^{\prime} \mathrm{S}$ and $2^{\circ} 40^{\prime} \mathrm{S}$ ), but, unfortunately, Siciliano et al. (2008) did not provide the precise location where pantropical spotted dolphins were sighted off northeastern Pará state and, thus, as this latter state is crossed by the Equator, it is not clear whether that sighting event occurred in the Southern or Northern Hemisphere. Therefore, considering just these two latter references as information sources of the northern distribution of the species in Brazil, it is possible that the present sighting of S. attenuata represents the northernmost published record of the species in SWA. However, if unpublished sightings of pantropical spotted dolphins available at the Sistema de Apoio ao Monitoramento de Mamíferos Marinhos (SIMMAM) (http:/ / simmam.acad.univali.br/ site) are taken into account, this report constitute just a new record of the northern distribution of S. attenuata in SWA.

Further studies in offshore waters along the Brazilian coast are essential for a better understanding of cetacean ecology and to confirm species distribution represented in coarse-scale maps, which are mostly represented by generalizations based on cumulative knowledge about their distribution over time, and, more recently, predicted through ecological modeling (Amaral et al., 2015; Rocha et al., 2019). Such surveys would not only 
provide a more complete description of the distribution pattern of Stenella dolphins in SWA but also might fulfill gaps on the occurrence of certain still unreported species in sites where they are suitable to be found, technically supporting ecosystem-based conservation initiatives in the region (IWC, 2016; Soares \& Lucas, 2018; Giglio et al., 2018).

In addition, it is worth noting that although $S$. attenuata do not seem to be as threatened by T. albacares fishery in northeast Brazil (where the great majority of the tuna fishery carried out, known as 'associated school fishery', uses pole and line, handlines and trawling as fishing methods (Silva et al., 2019)) as they are in other parts of the world where purse-seine are the prevailing tuna fisheries, hooked marine mammals have been recorded either in longline or handline fishing gears worldwide (Passadore et al., 2015; Werner et al., 2015; Anderson et al., 2020). Indeed, negative interactions between associated school tuna fishery and other cetacean species off Northeastern Brazilian coast were already observed: the decrease of landings and low profits caused by false killer whales (Pseudorca crassidens (Gray, 1846)) preying upon the targeted species (Silva et al., 2016). So, potential impacts of tuna fisheries on pantropical spotted dolphins populations from SWA shall also be investigated.

Acknowledgements - The author is grateful to the Brazilian Navy/NPa Macau crew (specially to Corvett Captain Paredes, the commander of the patrol vessel, and Corporal Itajibá, who first noticed the presence of dolphins beside the ship) as well as to Dr. Marcos Santos (IO-USP), Aline Cerqueira (ZSL Institute of Zoology \& King's College London), Dr. Raymond Ward (University of Brighton) and the anonymous referee for reviewing and providing helpful comments that greatly improved the manuscript. Additionally, the author is thankful to Cristine Negrão and Vitor Carvalho (both from AQUASIS) for the information concerning $S$. attenuata strandings in Ceará state and SIMMAM records. This paper is dedicated to the memory and legacy of Dr. Manuel Antônio de Andrade Furtado Neto (prematurely passed away), who was a pioneer in marine mammal studies in Ceará state, encouraging, shaping and consolidating a new generation of researchers.

\section{REFERENCES}

Alves Júnior, T.T.; Ávila, F.J.C.; Oliveira, J.A.; Furtado Neto, M.A.A. \& Monteiro Neto, C. Registros de cetáceos para o litoral do estado do Ceará, Brasil. Arq. Ciên. Mar, Fortaleza, v. 30, p. 79-92, 1996.

Amaral, K.B.; Alvares, D.J.; Heinzelmann, L.; Borges-Martins, M.; Siciliano, S. \& Moreno, I.B. Ecological niche modeling of Stenella dolphins (Cetartiodactyla: Delphinidae) in the southwestern Atlantic Ocean. J. Exp. Mar. Biol. Ecol., v. 472, p. 166-179, 2015.

Anderson, R.C.; Herrera, M.; Ilangakoon, A.D.; Koya, K.M.; Moazzam, M.; Mustika, P.L. \& Sutaria, D.N. Cetacean bycatch in Indian Ocean tuna gillnet fisheries. Endanger. Species Res., v. 41, p. 39-53, 2020.

Assis, J.; Tyberghein, L.; Bosh, S.; Verbruggen, H.; Serrão, E. A. \& De Clerck, O. BioORACLE v2.0: extending marine data layers for bioclimatic modelling. Glob. Ecol. Biogeogr., v. 27, p. 277-284, 2017.

Barragán-Barrera, D.C.; Amaral, K.B.; Chávez-Carreño, P.A.; Farías-Curtidor, N.; Lancheros-Neva, R.; Botero-Acosta, N.; Bueno, P.; Moreno, I.B.; Bolaños-Jiménez, J.; 
Bouveret, L.; Castelblanco-Martínez, D.N.; Luksenburg, J.A.; Mellinger, J.; Mesa-Gutiérrez, R.; Montgolfier, B.; Ramos, E.A.; Ridoux, V. \& Palacios, D.M. Ecological niche modeling of three species of Stenella dolphins in the Caribbean Basin, with application to the Seaflower Biosphere Reserve. Front. Mar. Sci., v. 6, p. 10, 2019.

Bezerra, S.N. A pesca de peixe com linha e rede no estado do Ceará. Tese de doutorado, Programa de Pós-Graduação em Ciências Marinhas Tropicais, Universidade Federal do Ceará, 168 p., Fortaleza, 2013.

Costa, A.F.; Siciliano, S.; Emin-Lima, R.; Martins, B.M.L.; Sousa, M.E.M. \& Giarrizzo, T. Stranding survey as a framework to investigate rare cetacean records of the north and north-eastern Brazilian coasts. ZooKeys, v. 688, p.111-134, 2017.

Cypriano-Souza, A.L.; Meirelles, A.C.O.; Carvalho, V.L. \& Bonatto, S.I. Rare or cryptic? the first report of an Omura's whale (Balaenoptera omurai) in the South Atlantic Ocean. Mar. Mamm. Sci., v. 33, p. 80-95, 2016.

Di Tullio, J.C.; Gandra, T.B.R.; Zerbini, A.N. \& Secchi, E.R. Diversity and distribution patterns of cetaceans in the Subtropical Southwestern Atlantic Outer Continental Shelf and Slope. PloS ONE, v. 11, n. 5, e0155841, 2016.

Gerrodette, T.; Olson, R.; Reilly, S.; Watters, G. \& Perrin, W. Ecological metrics of biomass removed by three methods of purse-seine fishing for tunas in the eastern tropical Pacific Ocean. Conserv Biol., v. 26, n. 2, p. 248-56, 2012.

Giglio, V.J.; Pinheiro, H.T.; Bender, M.G.; Bonaldo, R.M.; Costa-Lotufo, L.V.; Ferreira, C.E.L.; Floeter, S.R.; Freire, A., Gasparini, J.L.; Joyeux, J.C.; Krajewskie, J.P.; Lindnere, A.; Longo, G.O.; Lotufo, T.M.C.; Loyola, R.; Luiz, O.J.; Macieira, R.M.; Magris, R.A.; Mello, T.J.; Quimbayo, J.P.; Rocha, L.A.; Segal, B.; Teixeira, J.B.; Vila-Nova, D.A.; Vilar, C.C.; Zilberberg, C. \& FranciniFilho, R.B. Large and remote marine protected areas in the South Atlantic Ocean are flawed and raise concerns: Comments on Soares and Lucas (2018). Mar. Pol., v. 96, p. 13-17, 2018.

IWC. The South Atlantic: a sanctuary for whales. 2016. Available at: https://iwc.int/thesouth-atlantic-sanctuary. Accessed: 14 Nov. 2019.

Kellar, N.M.; Trego, M.L.; Chivers, S.J. \& Archer, F.I. Pregnancy patterns of pantropical spotted dolphins (Stenella attenuata) in the eastern ropical Pacific determined from hormonal analysis of blubber biopsies and correlations with the purse-seine tuna fishery. Mar. Biol., v. 160, n. 12, p. 3113-3124, 2013.

Kiszka, J. \& Braulik, G. Stenella attenuata. The International Union for Conservation of Nature Red List of Threatened Species. 2018. Available at: https://www.iucnredlist.org/ species/20729/50373009. Accessed: 6 Aug. 2019.

Lennert-Cody, C.E.; Maunder, M.N.; Fiedler, P.C.; Minami, M.; Gerrodette, T.; Rusin, J.; Minte-Vera, C.V.; Scott, M. \& Buckland, S.T. Purse-seine vessels as platforms for monitoring the population status of dolphin species in the eastern tropical Pacific Ocean. Fish. Res., v. 178, p. 101-113, 2016.

Lodi, L. \& Borobia, M. Anomalous coloration in an Atlantic spotted dolphin (Stenella frontalis) from Southeastern Brazil. Braz. J. Aquat. Sci. Technol., v. 17, n. 2, p. 1-3, 2013.

Martins, A.M.A.; Alves Junior, T.T.; Furtado Neto, M.A.A. \& Lien, J. The most northern record of Gervais beaked whale, Mesoplodon europaeus (Gervais, 1855), for the southern hemisphere. Lat. Am. J. Aquat. Mamm., v. 3, p. 151-155, 2004. 
Meirelles, A.C.O. \& Furtado Neto, M.A.A. Stranding of an Antarctic minke whale, Balaenoptera bonaerensis, Burmeister, 1867, on the northern coast of South America. Lat. Am. J. Aquat. Mamm., v. 3, p. 81-82, 2004.

Meirelles, A.C.O.; Monteiro Neto, C.; Martins, A.M.A.; Costa, A.F., Barros, H.M.D.R. \& Alves, M.D.O. Cetacean strandings on the coast of Ceará, north-eastern Brazil (1992-2005). J. Mar. Biol. Assoc. U. K., v. 89, p. 1083-1090, 2009.

Meirelles, A.C.O.; Ribeiro, A.C.; Silva, C.N.P. \& Soares Filho, A.A. Records of Guiana dolphin, Sotalia guianensis, in the State of Ceará, Northeastern Brazil. Lat. Am. J. Aquat. Mamm., v. 8, n. 1-2, p. 97-102, 2010.

Meirelles, A.C.O.; Choi, K.F. \& Oliveira, M.S. First reported stranding of a dwarf minke whale, Balaenoptera acutorostrata (Lacépède, 1804), on the coast of Ceará, Northeastern Brazil. Arq. Ciên. Mar, Fortaleza, v. 44, n. 2, p. 106-109, 2011.

Mignucci-Giannoni, A.A.; Swartz, S.I.; Martínez, A.; Burks, C.M. \& Watkins, W.A. First Records of the Pantropical Spotted Dolphin (Stenella attenuata) for the Puerto Rican Bank, with a Review of the Species in the Caribbean. Caribb. J. Sci., v. 39, n. 3, p. 381-392, 2003.

Moreno, I.B.; Zerbini, A.N.; Danilewicz, D.; Santos, M.C.O.; Simões-Lopes, P.C.; LailsonBrito Jr., J. \& Azevedo, A.F. Distribution and habitat characteristics of dolphins of the genus Stenella (Cetacea: Delphinidae) in the southwest Atlantic Ocean. Mar. Ecol. Prog. Ser., v. 300, p. 229-240, 2005.

NOAA. National Oceanic and Atmospheric Administration: US Bathymetric and Fishing Maps-Version: 2.3.0. 2019. Available at: https://maps.ngdc.noaa.gov/viewers/fishmaps. Accessed: 16 Jul. 2019.

NOAA. National Oceanic and Atmospheric Administration: Global Tropical Moored Buoy Array. 2020. Available at: https://www.pmel.noaa.gov/tao/drupal/pirata-display. Accessed: 5 Mar. 2020.

Passadore, C.; Domingo, A. \& Secchi, E.R. Analysis of marine mammal bycatch in the Uruguayan pelagic longline fishery operating in the Southwestern Atlantic Ocean. ICES J. Mar. Sci., v. 72, n. 5, p. 1637-1652, 2015.

Perrin, W.F. Distribution and differentiation of populations of dolphins of the genus Stenella in the Eastern Tropical Pacific. J. Fish. Res. Board Can., v. 32, n. 7, p. 1059-1067, 1975.

Perrin, W.F. Stenella attenuata. Mamm. Species, v. 683, p. 1-8, 2001.

Perrin, W.F. Pantropical spotted dolphin: Stenella attenuata, p. 676-678, in Würsig, B.; Thewissen, J.G.M. \& Kovacs K.M. (eds.), Encyclopedia of marine mammals. Academic Press, 1190 p., 2018.

Perrin, W.F.; Mitchell, E.D.; Mead, J.G.; Caldwell, D.K.; Caldwell, M.C.; van Bree, P.J.H. \& Dawbin, W.H. Revision of the spotted dolphins, Stenella spp. Mar. Mamm. Sci., v. 3, p. 99$170,1987$.

Ribeiro, F.B.; Carvalho, V.L.; Belilaqua, C.M.L. \& Bezerra, L.E.A. First record of Xenobalanus globicipitis (Cirripedia: Coronulidae) on Stenella coeruleoalba (Cetacea: Delphinidae) in the oligotrophic waters of north-eastern Brazil. Mar. Biodivers. Rec., v. 3, e8, 2011.

Rice, D.W. Marine mammals of the world: systematics and distribution. The Society for Marine Mammalogy, 231 p., Lawrense, 1998. 
Rocha, A.; Marchetto, C.; Pacheco, L. \& Secchi, E.R. Occurrence of blue whales (Balaenoptera musculus) in offshore waters of southeastern Brazil. Mar. Biodivers. Rec., v. 12, p. 1-5, 2019.

Scott, M.D.; Chivers, S.J.; Olson, R.J.; Fiedler, P.C. \& Holland, K. Pelagic predator associations: tuna and dolphins in the eastern tropical Pacific Ocean. Mar. Ecol. Prog. Ser., v. 458, p. 283-302, 2012.

Siciliano, S.; Emin-Lima, N.R.; Costa, A.F.; Rodrigues, A.L.F.; Magalhães, F.A.; Tosi, C.H.; Garri, R.G.; Silva, C.R. \& Silva Júnior, J.S. Revisão do conhecimento sobre os mamíferos aquáticos da costa norte do Brasil. Arch. Mus. Nac. (Rio de J.), Rio de Janeiro, v. 66, n. 2, p. 381-401, 2008.

Silva, G.B.; Hazin, H.G.; Mourato, B.L.; Hazin, F.H.V. \& Fonteles Filho, A.A. Composição das capturas na pesca de atuns e afins em cardumes associados no Atlântico Oeste Equatorial. Bol. Inst. Pesca, São Paulo, v. 42, n. 4, p. 866-877, 2016.

Silva, G.B.; Hazin, H.G.; Hazin, F.H.V. \& Travassos, P. The tuna fisheries on "associated school" in Brazil: description and trends. Collect. Vol. Sci. Pap. ICCAT, v. 75, n. 7, p. 19241934, 2019.

Soares, M.O \& Lucas, C.C. Towards large and remote protected areas in the South Atlantic Ocean: St. Peter and St. Paul's Archipelago and the Vitória-Trindade Seamount Chain. Mar. Pol., v. 93, p. 101-103, 2018.

Werner, T.B.; Northridge, S.; Press, K.M. \& Young, N. Mitigating bycatch and depredation of marine mammals in longline fisheries. ICES J. Mar. Sci., v. 72, n. 5, p. 1576-1586, 2015. 